\title{
Commonwealth Financial Dominance, Fiscal Balance or Reverse Revenue Sharing?
}

\author{
Robert Albon
}

B EFORE federating in 1901, the Australian colonies each enjoyed a balance of taxing and spending responsibilities. After federation, Section 90 of the Constitution gave the Commonwealth exclusive power over two major taxes - customs and excise - but limited its spending responsibilities to defence and foreign affairs. Further, the Commonwealth was not only given the power to make financial payments to the States, but under the Braddon Clause it was obliged to transfer to the States at least 75 per cent of customs and excise revenue. ${ }^{1}$

Since federation, the Commonwealth's relative role in spending has increased. But its role in taxation has increased even more. The Commonwealth is now responsible for nearly 80 per cent of all taxation, but the States undertake about 45 per cent of all government spending. If 'vertical fiscal balance' means that each level of government is responsible for its own revenue raising, then Australia exhibits a high degree of vertical fiscal imbalance, firmly in the direction of Commonwealth dominance. The degree of imbalance, in terms of the shares of total revenue raised at each level, is greater in Australia than in any of the major federations, and, indeed, some non-federal countries. ${ }^{2}$

The existing fiscal imbalance seems to be supported by both major tiers of government. State governments, particularly those in the 'claimant' States, seem content to raise only a relatively small proportion of their revenue needs and to rely on the Commonwealth to levy nearly all of the major taxes, perhaps because this prevents an erosion of their revenues through inter-State competition and allows them to claim the political benefits from spending while attributing the political costs of taxation to the Commonwealth. Although its position may be changing, the Commonwealth also has participated more or less willingly in these arrangements.

The orthodox view is that Commonwealth tax dominance is desirable because it is essential for macroeconomic management and helps facilitate more equal serv-

\footnotetext{
${ }^{1}$ Named after Sir Edward Braddon, Premier of Tasmania at the time of the 1897 Adelaide Convention. The Commonwealth Grants Commission is now located in Braddon, a Canberra suburb. ${ }^{2}$ Grewal (1995) discusses different ways of measuring vertical fiscal balance and presents comparisons with other federations.
}

Robert Albon is Senior Lecturer in Economics in the Faculty of Economics and Commerce at The Australian National University. 
ice provision across the States (see some of the contributions in Collins, 1993). But the existing arrangements have given rise at least three grounds for concern. First, to the extent that they amount to a tax cartel, they could be raising an excessive amount of revenue. Second, State governments which do not raise the bulk of the revenue necessary to sustain their spending programs may lack accountability. Third, the present arrangements could be maintaining an inefficient mix of tax revenues, in particular by excluding the States from the major tax bases.

In response to these concerns, some commentators have advocated moving to or towards fiscal balance, primarily by substantially reallocating taxation responsibilities to the States, but in some cases also by reallocating expenditure responsibilities. Such balancing would require either allowing the States to fund more of their expenditure from existing State taxes or giving States a share in existing Commonwealth revenue bases. This article contains a detailed consideration of each of these balancing options. As expenditure assignment has not been particularly important in the Australian debate, and also for reasons of space, it is given no further consideration here. However, another, more radical, reform option - 'reverse revenue sharing' - involving reversing the existing fiscal imbalance, is considered. Under this approach the States would raise more revenue than they spend and make grants to the Commonwealth rather than vice versa.

\section{The Development of Commonwealth Dominance}

Two key provisions - the Commonwealth's exclusive power with respect to customs and excise and the Braddon Clause - provided the basis for the development of vertical fiscal imbalance, which although much less pronounced than now, began immediately with federation. ${ }^{3}$ In 1901-02, the Commonwealth raised around 42 per cent of all revenue (excluding borrowing), but undertook only about 5 per cent of all government spending. Conversely, States and local authorities were responsible for around 58 per cent of non-borrowing revenue and approximately 95 per cent of all government spending. As borrowing was heavy at the time, the States' revenue effort represented about 40 per cent of their own revenue requirements.

During the first four decades of federation, the Commonwealth gradually assumed a greater role in taxation without a commensurate increase in its spending role, and the States also increased their revenue-raising effort. By 1909-10, the States were raising about 65 per cent of their revenue requirements from sources other than the Commonwealth and borrowing. The Commonwealth progressively supplemented its customs and excise revenues by moving into direct taxation: the land tax in 1910, estate duties in 1914, and - a major turning-point - the federal income tax in 1915. These moves into direct taxation, while not having a substantial immediate impact on revenue shares, provided the foundation for a big expansion of the Commonwealth's role.

In 1918-19, the States' own non-borrowing funding was still covering around 65 per cent of their requirements. But fiscal imbalance began gradually to decrease in

\footnotetext{
${ }^{3}$ Mathews and Jay (1972) is the major source of the historical data in this section.
} 
the 1920s, as the States assumed an increasing share of the tax burden. By 193839 , they were were raising revenue from taxes, charges and public enterprise surpluses equivalent to about 70 per cent of their spending.

Wartime contingencies reversed this trend and resulted in much greater Commonwealth dominance. Mathews and Jay (1972:Ch. 7) provide a useful account of the Commonwealth's assumption of exclusive power over income taxation in 1942. The war effort required high revenues, and a Special Committee on Uniform Taxation was established. It recommended adoption of a single federal income tax, with compensation of the States according to the average of their income tax revenues in the financial years 1939-40 and 1940-41. Four Acts of Parliament ensued, establishing the machinery of the federal income tax.

As the Commonwealth government effectively assumed exclusive income taxing powers, substantially increasing its own tax raising activity, the States simultaneously lost their largest tax. By 1948-49, the States and local governments together were raising only 34 per cent of their revenue requirements in taxes, charges, and profits from trading enterprises, less than half the proportion of ten years carlier. Thereafter, the extent of this vertical imbalance decreased slightly, with the proportion of State and local government spending raised by their own revenue-raising activities varying between about 25 per cent and 34 per cent. The return of payroll taxes to the States in 1971 represented a reversal of the trend, but had only a small effect on overall balance. Since the late 1980 s, the imbalance has again fallen slightly, with the Commonwealth 'squeezing' the States through reductions in their grants, so forcing them to increase their dependence on their own revenue sources. The States now raise about 40 per cent of their revenue requirements.

\section{Difficulties with Commonwealth-Dominated Vertical Fiscal Imbalance}

The word 'imbalance' implies there is something wrong with the existing structure of taxation by different levels of government. Three main concerns have been expressed: lack of tax competition (possibly leading to excessive revenue collection); lack of accountability of State governments; and an inefficient mix of aggregate taxation collection. We treat each conccrn in turn.

Insufficient tax competition. An important idea of public choice theory is that governments may not act in the public interest and may instead pursuc their own selfinterest by, for example, maximising their budgets or revenues (Brennan \& Buchanan, 1980). To the extent that governments do this, they may exercise their monopoly powers over taxation to extract inefficiently high taxation revenues. The public choice analysis of government has contributed to the view that competition among governments can contribute to the general welfare by making government more responsive to the preferences of citizen/voters. A system of 'competitive federalism' could limit the ability of governments to put their self-interest before the public interest.

An alternative view is that competition among State governments has mainly negative consequences. Models of tax competition with few governments and stra- 
tegic interactions among them usually assume that that regional governments behave in the public interest (rather than in their self-interest, as in the public choice literature); adopt Nash behaviour; ${ }^{4}$ voluntarily contribute to a public good paid for by taxes on a mobile tax base, usually capital; and are identical in terms of preferences, populations and incomes. The standard result is that tax competition leads to under-provision of local public goods.

There has been some debate about whether the aggregate Australian tax burden is excessive, just right, or deficient relative to the efficient level of government expenditure. This is a difficult issue to resolve (see Withers et al., 1994, and Cox, 1995). The fact that many groups call for increased government expenditure in a variety of areas is not conclusive evidence of a real community demand for increased expenditure in these areas, much less overall. Individuals are less inclined to demand more when they are reminded of the tax cost involved. Withers et al. (1994) found that people wanted government spending to be cut in some areas, as well as increased in others. Further, various studies have found evidence of inefficiency in the provision of many government services.

Insufficient accountability. The idea that matching taxation and responsibilities at different levels of government promotes accountability and efficiency has a strong grounding in the public choice literature. It has been articulated in Australia on many occasions. For example, the Draft White Paper that preceded the 1985 taxation summit recognised the importance of accountability:

It is sometimes argued that fiscal responsibility would be enhanced if each level of government had to raise - and had powers to raise - the revenue necessary to satisfy its expenditure commitments. This question, which relates to the distribution of tax powers, raises many important and complex issues. Important as some of these are (e.g. the effects of payroll tax and stamp duties), the Government does not believe it is practical to deal with them in the context of this review. (Australian Treasurer, 1985:17)

Similarly, accountability lies behind the suggestion by Wayne Goss, a former Queensland premier, of a move to fiscal balance:

First and foremost, the Australian federation for the twenty-first century must be one in which expenditure responsibilities for the States and Territories are commensurate with their revenue raising capacity. . . Vertical fiscal imbalance must either be eliminated or else reduced to the sorts of levels ... in other comparable federations. (Goss, 1995:12)

\footnotetext{
${ }^{4} \mathrm{~A}$ 'Nash equilibrium' is one where each party (in this case, government) is doing the best it can given what every other party (government) is doing.
} 
However, it can be argued that there is a sense in which State governments are accountable for their spending, at least at the margin. ${ }^{5}$ Where a State government wishes to pursue a new spending initiative, it will not usually receive supplementary Commonwealth funding, but has to generate the funds at the State level. In this circumstance there is 'accountability' for its action.

Inefficient mix of taxation. State taxes tend to have narrow bases and high rates, and sometimes 'piggy-back' on Commonwealth taxes to result in high combined rates. In contrast, the Commonwealth has access to broader bases, particularly income, allowing it to impose lower rates. While the empirical information and analysis required to judge the relative effects on efficiency of different taxes (that is, estimates of the marginal deadweight losses from raising a dollar of revenue in different ways) is not always available, especially at the State level, present State taxes are probably broadly inferior in terms of efficiency to Commonwealth taxes, and a reduced reliance on existing State taxes would probably improve the efficiency of overall tax collection. ${ }^{6}$ However, the States probably could exploit their available tax bases, especially land and the payroll, more efficiently than at present.

\section{Proposals for Improving Balance}

Coordination of existing State tax efforts. Individual States have advocated reducing the degree of imbalance by increasing the revenue from existing taxes, especially through coordination of taxation efforts. This was a feature of the major reviews in the two most populous States, New South Wales (New South Wales Tax Task Force, 1988) and Victoria (Committee of Inquiry into Revenue Raising in Victoria, 1983). Both reports recommended the establishment of a coordinating body.

The New South Wales report was concerned, inter alia, with the prevention of tax competition. Chapter 29 advocated the establishment of an 'Interstate Tax Commission' to 'harmonise' State taxes. The Victorian report called for an explicit Commonwealth-State financial contract, greater coordination of taxation collection between the States and the Commonwealth (with a new coordinating body, the Standing Committee of Treasurers); the introduction of a broad-based consumption tax and a small income-tax surcharge; and the removal of various anomalies and exemptions in many existing taxes.

Implementation of these proposals would have improved the accountability position of State governments by matching revenue-raising more closely with expenditure. However, this gain would be offset by two possible losses. First, to the extent that governments act in a self-interested manner, the taxation cartel would have been strengthened, with consequent increased efficiency losses. Second, while State revenues would be raised more efficiently, the aggregate tax mix could have become less efficient to the extent that Commonwealth taxes were reduced. (The overall national tax mix would be shifted towards taxes on payrolls, land, and finan-

\footnotetext{
${ }^{5}$ I am grateful to a referee for pointing out this possibility.

${ }^{6}$ Reviews of the efficiency of State taxation include Industry Commission (1994) and Albon (1993).
} 
cial transactions, and away from those on incomes and goods and services, possibly increasing the net aggregate efficiency costs of raising a given amount of revenue.)

State income tax. Since the States lost their income taxing power in 1942, only rather half-hearted attempts have been made to restore it; and an offer to give it back was not accepted. Under the Fraser Government's 'New Federalism' policy in the late $1970 \mathrm{~s}$, the States, as a whole, were allocated a fixed share of total income tax receipts as the general revenue grants pool, and were given limited powers to impose their own income taxes as a surcharge on the Commonwealth's income tax. Only Western Australia passed the complementary legislation, and no State took up the opportunity to raise its own income tax.

More recently, the States put forward their own plan for income taxation (Working Party on Tax Powers, 1991), under which they were to be accountable for an identifiable component of income tax collections. This component was to be set at six cents in the dollar of taxable income for the first three years with an equivalent reduction in the Commonwealth rate; thereafter, any proposed changes to the States' rates, either individually or collectively, were to be agreed upon in negotiations between the Commonwealth and the States through the proposed Council of the Australian Federation. In the initial year of the new arrangements there was to be an offsetting reduction in Commonwealth grants to the States. Further, to increase accountability, Commonwealth and State components of the income tax would have been clearly identified.

Implementation of this plan would have made State governments more accountable, and probably would have improved the efficiency of the aggregate tax mix. However, a diminution of tax competition, flowing from the proposed common tax base, could have introduced inefficiencies. Further, for the first three years of its operation, tax rate competition would have becn ruled out by the fixed six cents in the dollar. Tax rate competition may have emerged after this initial period, since whereas rates were previously set cooperatively (that is, by the Commonwealth), they were henceforth to be set somewhat independently by the States. However, collusive behaviour could have emerged instead, since rates after the initial three-year period were to be set in negotiations between the Commonwealth and the States through the proposed Council of the Federation.

The plan thus offered some prospect of tax competition with respect to income tax rates. The literature on inter-regional competition suggests that, to the extent that governments behave in their own interest, rather than the public interest, competition offers significant efficiency gains by increasing the responsiveness of government to the wishes of citizens. However, to the extent that governments pursue the public interest, inter-regional competition may create efficiency losses by pushing tax rates, revenues and provision of local public goods below socially optimal levels. Thus, whether competition is desirable depends, at least in part, on what motivates government behaviour. 
State involvement in a goods and services tax. State involvement in a broad-based consumption tax was recommended in the Committee of Inquiry into Revenue Raising in Victoria (1983). However, Section 90 of the Constitution precludes the States from imposing their own excise taxes, although the interpretation of what constitutes an excise tax has been much debated. The States levy business franchise fees that appear to be similar to excises. The validity of these 'fees' has recently been reaffirmed by the High Court following the Capital Videos ruling, where an ACT pornographic video distributor successfully challenged the validity of the ACT Government's business franchise fee on its sales. Unless the words 'and excise' are deleted from Section 90, the Constitution will continue to bar the States from gaining independent access to this base.

Alternatively, the States could be given access to a guaranteed percentage of Commonwealth indirect taxation revenues through a revenue-sharing rule. Effectively this is what the Liberal-National coalition suggested in its Fightback! package prior to the 1993 election. The proposal was to abolish State payroll taxes and replace the revenue lost with Commonwealth grants linked to the proposed Goods and Services Tax (GST) base. The arrangements reflected the principle of revenue neutrality (for both the Commonwealth and the States); they would ensure growth in the grants in line with growth in the GST base, and provide maximum possible security for the grants from interference by future Commonwealth governments.

To meet these objectives, the coalition proposed to embody the arrangements in legislation which provided that:

... in the year of the abolition of the payroll tax each State would receive a separately identified 'Payroll Tax Abolition Grant' from the Commonwealth equal to the average of its total payroll tax collections over the three prior years, where prior year collections are escalated to dollars of the day by the CPI ... The amount of each State's Grant so calculated would be expressed as a percentage of the GST base. This process would ensure that payroll tax abolition grants automatically grew in line with the growth in the GST base. The incorporation of these provisions in legislation would provide a guarantee for the States that, in the future, Governments would find it very difficult to renege on the arrangements. (Liberal and National Parties of Australia, 1991:7)

This solution would only have introduced 'notional' accountability for the States, since a State could claim it had no control over the definition of the tax base, the setting of rates, or the determination of the sharing rule itself. The denial of direct responsibility for revenue raised in this way would have been little different from the current situation with respect to untied grants from the Commonwealth.

As the Commonwealth would have set the GST rate, unlike the States' plan there would have been no increase in tax competition. Indeed, the proposal may have decreased tax competition by abolishing one tax — namely, the payroll tax on which States appear to compete, and replacing it with a revenue source on which 
there is no interstate competition. Hence, the Fightback! proposals could well have reduced the overall degree of tax competition (Albon \& Petchey, 1993). However, they did, like the States' plan, offer the potential of shifting the national tax mix in favour of taxes with possibly lower efficiency costs than existing State taxes. Indeed, this was the potential benefit that the Coalition emphasised.

\section{Reverse Fiscal Imbalance}

Balancing expenditure and taxation responsibilities could well result in gains. But vertical fiscal imbalance could be reversed, so that States raise more revenue than they spend, enabling them to make grants to the Commonwealth rather than vice versa. This would involve a constitutional change allowing the States access to excise taxes.

Buchanan and Lee have suggested a fiscal union for the European Union based on 'reverse revenue sharing'. In the extreme form they advocate there would be

... a fiscal structure where the only power to tax resides within the political subunits of the central government ... The political subunits should, in turn, be required to 'share' with the central government some fixed percentage (which should be uniform over all subunits) of the tax revenue they raise . . (Buchanan \& Lee, 1994:224)

Interestingly, a less absolute version of reverse revenue sharing emerged in Australia in the early $1920 \mathrm{~s}$, partly through a Minority Report of the 1921 Royal Commission on Taxation, appointed by the Commonwealth in 1920 to consider ways of achieving 'harmonisation' of federal and State taxes (Commonwealth of Australia, 1921). The report itself recommended centralisation of collection, and uniformity of personal income taxation, but stopped short of recommending exclusive federal powers over the personal income tax. The minority commissioner favoured the States having exclusive powers over direct taxation, and the payment of per capita grants to the Commonwealth. In a similar vein, a plan was promoted by the then government to move towards fiscal balance by the Commonwealth, first, vacating most direct taxation, and second, stopping grants to the States. This proposal was rejected by the States, and was strongly condemned by contemporary economists such as Copland (1924) and Mills (1928). The latter argued that

... it is to be remembered that this 'vicious principle' has been followed in Australian financial practice for 27 years, and that the States, who might be supposed to suffer, have not only not protested, but have been entirely satisfied with its operation. (Mills, 1928:70)

To the extent that the States adopted a cartelised revenue-raising arrangement, reverse revenue sharing would effectively substitute a taxation cartel for the existing Commonwealth taxation monopoly. However, to the extent that the States com- 
peted, overall tax collections would fall, representing a net efficiency gain so long as the Commonwealth had not exploited its monopoly position.

Reverse revenue sharing would probably make for a more efficient mix of overall taxation, involving a substitution of broad-based taxes for rather narrowbased ones with high marginal deadweight losses. Effectively, the States would be able to discard much of the grab-bag of inefficient taxes forced upon them by the Constitution and the centralisation of income taxation in 1942.

Finally, reverse revenue sharing would appear at first to make for less accountability than would fiscal balance, since it would recreate a divergence of taxation and expenditure responsibilities. However, an offsetting benefit would be the restriction on the ability of the central government to give in to special interest groups, since it would be unable to spread the burden of the resulting extra spending over taxpayers in the States. Further, at the margin, State governments would have no alternative but to impose the full cost of expenditure initiatives on their own citizens.

\section{Conclusion}

While the Australian federal system has worked tolerably well, the degree of vertical fiscal imbalance involves a lack of tax competition, insufficient accountability of State governments, and an inefficient aggregate mix of taxation revenue. Two responses to these problems - the States' plan and the Fightback! proposals promise efficiency gains from rebalancing the national tax mix in favour of, respectively, income taxes and a consumption tax. A third proposal, reverse revenue sharing, would retain fiscal imbalance, but tip it towards the States. It could bring benefits in terms of tax competition, efficiency of the tax mix, and accountability.

The new federal government is showing signs of a willingness to consider alternatives to Commonwealth tax dominance. As well, there are signs of a new popular interest in exploring Australian federalism's potential for further decentralising government away from the Commonwealth. The agenda of the Constitutional Convention due to meet in 1997 should include Australia's tax arrangements, which, more than any other factor, will determine whether the Australian States are destined to be more than merely branch offices of the Commonwealth.

\section{References}

Albon, R. (1993), 'Taxation', pp.216-33 in D. Hughes \& R. Albon (eds), Capital Ideas: Suggestions for Economic Reform in the ACT, Federalism Research Centre, Australian National University, Canberra.

— \& J. Petchey (1993), 'Federalism Aspects of Fightback', pp.551-65 in J. Head (ed.), Fightback' An Economic Assessment, Australian 'Tax Research Foundation, Sydney (Conference Series No. 12).

Australian Treasury (1985), Draft White Paper: Reform of the Australian Taxation System, Canberra.

Bremnan, H. \& J. Buchanan (1980), The Power to Tax: Analytic Foundations of a Fiscal Constitution, Cambridge University Press, Cambridge. 


\section{Robert Albon}

Buchanan, J. \& D. Lee (1994), 'On a Fiscal Constitution for the European Union', Journal des Economistes et des Etudes Humaines 5(2/3): 219-32.

Collins, D. (ed.) (1993), Vertical Fiscal Imbalance, Australian Tax Research Foundation, Sydney.

Commonwealth of Australia (1921), Report of the Royal Commission on Taxation, Government Printer, Melbourne.

Committee of Inquiry into Revenue Raising in Victoria (J. Nieuwenhuysen, Chair) (1983), Report, Government Printer, Melbourne.

Copland, D. (1924), 'Some Problems of Taxation in Australia', Economic Joumal, September: 38797. Reprinted in Prest \& Mathews (eds) .(1980:35-45).

Cox, J. (1995), 'How Much Spending? The EPAC Survey of Public Expenditure Preferences in Australia', Agenda 2(2): 245-8.

Goss, W. (1995), 'Restoring the Balance: The Future of the Australian Federation', Federalism Research Centre, Australian National University, Canberra (Address to a Seminar on Federal/State Relations hosted by the Federalism Research Centre, Old Government House, Brisbane, 10 July).

Grewal, B. (1995), 'Vertical Fiscal Imbalance in Australia: A Problem for Tax Structure, not for Revenue Sharing', Centre for Strategic Economic Studies, Victoria University of Technology, Melbourne, March (Working Paper No. 2).

Industry Commission (1994), 'Efficiency and Equity in State and Territory Taxation and Australia's Economic Performance', Appendix B of Amnual Report 1.993-94, AGPS, Canberra.

Liberal and National Parties of Australia (1991), Fightback! Taxation and Expenditure Reform for Jobs and Growth, Supplementary Paper No. 7, Canberra.

Mathews, R. \& W. Jay (1972), Federal Finance: Intergovernmental financial relations in Australia since Federation, Nelson, Melbounc.

Mills, R. (1928), 'The Financial Relations of the Commonwealth and States', Eronomic Record 4: I14. Reprinted in W. Prest \& R. Mathews (1980:63-76).

New South Wales Tax Task Force (D. Collins, Chair) (1988), Review of the Statc Tax System, NSW Government Printer, Sydney, August.

Prest, W. \& R. Mathews (eds) (1980), The Development of Australian Fiscal Federalism, Australian National University Press, Canberra.

Withers, G., D. Throsby \& K. Johnston (1994), Public Expenditure in Australia, Economic Planning Advisory Commission, Canberra (Commission Paper No. 3).

Working Party on Tax Powers (1991), 'Taxation and the Fiscal Imbalance Between Levels of Australian Government Responsibility, Accountability and Efficiency', Report prepared for the November 1991 Special Premiers' Conference, October.

I am grateful to Jeff Petchey for previous collaboration on federal-State issues and to two anonymous referees for very helpful comments. 